\title{
Sustainable Solid Waste Management for Rural Area
}

\author{
Mr. Kale Tejas Sunil ${ }^{1}$, Dr. A.C.Attar ${ }^{2}$ \\ ${ }^{1,2}$ (Civil department, RIT, Islampur, India)
}

\begin{abstract}
In this paper we have studied solid waste management in Gotkhindi village near Islampur. The predominance of open dumping and the absence of reliable data regarding generation and characterization of waste has created a difficult situation for rural local bodies responsible for managing solid waste generated in the village. In this study, solid waste samples collected from a dump site analyzed for physical characterization. The physical characterization of the city waste confirms its suitability for applying biological method of composting. The waste characterization highlights the importance of waste segregation before sending the waste fractions for different waste-treatment technologies including composting and landfilling. Most common practice of waste processing is uncontrolled dumping which causes pollution. If the wastes are disposed in an uncontrolled manner these may cause adverse impact on public health \& environment. Therefore, the solid wastages are still a major problem in this rural area. To overcome these problems, we have proposed to implement Bangalore method of composting.
\end{abstract}

Keywords: Bangalore method of composting, open dumping, pollution, solid waste, waste characteristics.

\section{Introduction}

Solid waste has become one of the biggest problems and its management is one of the major issues now days for our environment. Developing countries face major problem i.e. solid waste management in urban as well as in rural areas. It is necessary to have accurate information on planning a proper solid wastes management in rural areas of country. On the other hand, lack of knowledge on the unfavorable health outcomes of solid wastes has increased the occurrence of infectious diseases [1]. In the present scenario, with the fast growth and development of economies, especially in the developing countries, solid waste generation and its management has emerged as a continually growing problem at global, regional, and local levels. The collection of reliable data regarding generation and characterization of the waste is the key to a successful solid waste management. Presently, lack of reliable information and data regarding generation rate, amount, and nature of solid waste creates an obstacle in developing an appropriate waste management plan. The objective of solid waste management in rural areas is to collect the waste at the source of generation, recovery of recyclable materials for recycling, conversion of organic waste to compost and secured disposal of remaining waste [2].

\subsection{Existing Solid Waste Management Practice}

\section{Materials and methods}

Present scenario of solid waste management practices in Gotkhindi village:

1. Street Sweeping and Collection Points - The sanitary workers of GP collect waste during street sweeping and dump it to the nearest collection point. The household waste is also dumped in the nearby collection point. Approximately 10 collection points or temporary waste storage exist the village. Collections points are either open spaces or open containers or concrete bins. Containers are not placed on the paved surface which results in mixing of fine materials like soil. At number of places, these bins are found overflowing or underutilized. The location of these bins is not properly sited.

At household level segregation of waste is nor done before disposing it collection point. Some of the household waste is thrown in gutters. Also no effort is taken from GP for segregation this waste.

2. Secondary Collection/Transportation - The tractor trolley system is used for collection of waste from community beans and transporting it to dumping site. This collection is done once in 2 months or after receiving complaints from public, whichever is earlier. The collection system is poorly planned. The solid waste transportation is done by tractors or three wheelers. Most of the waste loading is done manually. The garbage is loaded transportation vehicle without any segregation. At some collection points, garbage is burned and its ash is disposed in gutters.

3. Final Disposal of SW - The collected waste is disposed off at dumping area. The total area of the site is approximately 2 acres. Mixed solid waste is dumped in heaps without proper spreading and compaction, which causes unhygienic conditions. The waste is dumped without following by any segregation and applying soil covers. The garbage is dumped in heaps, without segregation. But nearby or local people collects reusable or recyclable products from dumped garbage. 
There is no data available on the quantity and composition of waste. Through personal visits to sites and discussion with officers, labours details have been collected which will form the basis of interpretation, calculations and recommendations of this paper.

\subsection{Sample Collection and Waste Characterization}

The solid waste sample was taken from dumping site. The $20 \mathrm{~kg}$ of solid sample was taken for waste characterization. The waste characterization is carried out to acquire information about composition of waste steam. It aids planner in decreasing landfill waste, to set up recycling programs and conserve money and resources. The average composition of waste by weight is estimated below,

Table 1 Waste Characterization

\begin{tabular}{|l|l|l|l|}
\hline Weight of Sample & \multicolumn{4}{|l|}{ Waste Characteristics } \\
\cline { 2 - 4 } waste collected $(\mathrm{kg})$ & Garbage $(\mathrm{kg})$ & Rubbish $(\mathrm{kg})$ & Others $(\mathrm{kg})$ \\
\hline $20(100 \%)$ & $9.4(47 \%)$ & $5.6(28 \%)$ & $5(25 \%)$ \\
\hline
\end{tabular}

\section{Waste Characteristics}

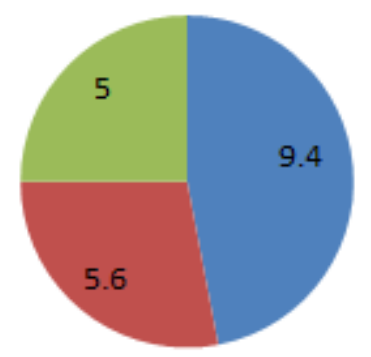

Garbage

Rubbish

Others

Figure 1 Waste characterization

The garbage comprises all sorts of biodegradable materials i.e. putrescible organic waste. Vegetable peelings, fruit peelings etc. are included in this term. The solid waste sample contains $9.4 \mathrm{~kg}$ of garbage (47\%). These wastes are organic in nature. The decomposition of these wastes produces foul odors and health hazards. They may also result in breeding of insects, flies etc. Hence, garbage must be disposed of quickly, by proper method. When it is scientifically composted then it can give valuable product like fertilizer, humus etc. The density of garbage usually varies between 450 to $900 \mathrm{~kg} / \mathrm{m}^{2}$. The rubbish includes a variety of combustible and incombustible materials. Paper, plastic, broken glass, crockery, metal etc. are included in this term. The solid waste sample contains $5.6 \mathrm{~kg}$ of rubbish (28\%). These types of wastes are generated from homes, offices, small commercial establishments. The density of rubbish usually varies between 700 to $850 \mathrm{~kg} / \mathrm{m}^{\mathrm{a}}$. The others include a variety of materials collected from street sweeping. Fine dust, sand, broken brick pieces, leaves etc. are included in these terms. The solid waste sample contains $5 \mathrm{~kg}$ of these types of waste $(25 \%)$.

The quantity of rubbish is small as compared to garbage, as large quantities of papers, plastics, cardboards; rags, etc. are picked by the rag pickers. This reduces the calorific value of waste. Also moisture content of waste is high, it cannot be easily burnt or incinerated, and hence the incineration method of waste disposal is not suitable for this type of waste.

\section{Recommended Solid Waste Management Plan for Village}

The village does not have any solid waste management plan. Hence, by considering safety of health of villagers and clean campus, following solid waste management plan is prepared.

\subsection{Estimating Total Quantity of Wastes Generated}

The population of Gotkhindi village is 7592, as per Sangli district census 2011. The rate of population growth during 2001-2011 for Sangli district is 16.1\%. For calculating population of 2025, by using Geometric increase forecasting method,

$$
\begin{aligned}
& P n=P o \times\left(1+\frac{r}{100}\right)^{n} \\
& \text { Where,Pn= future population, } \\
& \text { Po }=\text { present population, } \\
& r=\text { rate of population growth, }
\end{aligned}
$$




$$
\begin{array}{r}
n=\text { increse factor } . \\
P n=7592 \times\left(1+\frac{16.1}{100}\right)^{1.5}
\end{array}
$$

$$
=9497.39
$$

Say, $P n=9500$ No's.

The future population in year 2025 will be 9500 . The solid waste management system will be designed for this population.

Although only a few reliable statistics are available on generation of solid waste in India, yet Central Pollution Control Board (CPCB) has estimated that the daily per capita solid waste generation in India ranges from about $0.1 \mathrm{~kg}$ in small towns to about $0.5 \mathrm{~kg}$ in larger cities.

Assuming, solid waste generation in Gotkhindi is $250 \mathrm{gm}$. / cap / day.

Daily solid waste generation in weights/day $=9500 * 250$

$$
=2375000 \mathrm{gm} \text {. } / \text { Day }
$$

Daily solid waste generation in weights/day $=2375 \mathrm{Kg} / \mathrm{Day}$

Daily solid waste generation in volume/day $=2.375 \mathrm{~m}^{\mathrm{a}}=3 \mathrm{~m}^{\mathrm{a}}$ Say

Daily solid waste generation in volume/day $=3 \mathrm{~m}^{\mathrm{a}}$

\subsection{Proposed Management Organization}

For a future population producing approximately 3 Cubic Meters of waste weighing 3 Tons every-day is estimated. So, existing set up is inadequate. The operation of all services indicated in TERI specifications would need $1-3$ manual workers/1000 population and one heavy motor vehicle for about 20000 populations.

Manual workers needed $=2$ manual workers $/ 1000$ population

$$
\begin{aligned}
& =(2 * 9500) / 1000 \\
& =19 \text { No's } \\
& =\text { Say } 20 \text { No's }
\end{aligned}
$$

The organization of solid waste management services for Gotkhindi would need a set up as recommended below:

$$
\begin{array}{llr}
\text { - } & \text { Manual workers } & =20 \text { No's } \\
\text { - } & \text { Ward In charge /Supervisors = 1/ } 10 \text { manual workers } & =2 \text { No's } \\
\text { - } & \text { Administrator } & =1 \text { no. }
\end{array}
$$

\subsection{Collection and Transportation of Solid waste}

The door to door collection should be done by small vehicle system. The hand trucks / trolleys / pedal cycles having capacity of 300 liters and 500 liters and economical range of operation $1.5 \mathrm{~km}$, should be used for door to door collection. The hand trolley having two compartments should be used i.e. one for garbage and other for rubbish. The labor should segregate waste while collecting it. This will reduce further efforts of segregation. Size of hand trolley $=2 * 3 * 1.5 \mathrm{ft}$.

$$
\begin{aligned}
& =9 \mathrm{Cu} . \mathrm{ft} . \\
& =0.25 \mathrm{~m}^{2}
\end{aligned}
$$

Daily waste generation in volume/day $=3 \mathrm{~m}^{\mathrm{a}}$

Total number of hand trolleys required $\quad=3 / 0.25=12$ No's

Because of limited range of hand trolleys these vehicles cannot deliver the wastes direct to the disposal site. So to collect this daily waste at a single point called Community beans should be provided. For each ward one Community beans is needed. The Community beans vary from fixed storage bean, concrete pipe section, portable steel bins, masonry or concrete enclosures etc. All these verities were discussed with officials and it was agreed that many systems do not permit of thorough cleansing, such as storages in pipes on unpaved ground should not be adopted. The concrete or masonry enclosures facilitate thorough cleaning. The capacity of this collection bean should be such that it should provide weekly service. The collection bean should be provided with two compartments. It's important to store garbage and rubbish separately to reduce future expense of segregation. Also roof should be provided to collection beans, so than in monsoon season rain water will not enter into beans.

Provide community beans of capacity $6.75 \mathrm{~m}^{2}$ and dimensions $2.5 \mathrm{~m} * 3 \mathrm{~m} * 0.9 \mathrm{~m}$.

Therefore, total capacity of community beans $=5 * 6.75=33.75 \mathrm{~m}^{\mathrm{a}}$

Actual generation of total waste in 8 days $=8 * 3=24 \mathrm{~m}^{\mathrm{a}}$

The number of vehicles required for collection of waste from community beans and transportation to dumping site $=3$ 
The vehicle recommended for this purpose is 3 -wheeler - Mahindra Alfa plus tipper. Because, this vehicle is suitable to road conditions of village.

\subsection{Final Disposal of Solid Waste}

Bangalore method of composting

This method involves anaerobic decomposition of wastes. The waste and soil are piled up in layers in an underground earthen trench. This mass is covered at its top by layer of earth of about $15 \mathrm{~cm}$ depth and is finally left over for decomposition. Within 2 to 3 days of burial, intensive biological action starts taking place and organic matter begin to be decomposed. Considerable heat gets involved in the process, which raises the temperature of the decomposing mass to about 75 degree Celsius. This heat prevents the breading of flies by destroying the worms. After about 3 to 4 months, the refuse gets fully stabilized and changes into brown colored, odorless innocuous powder mass, called humus. This humus is removed from the trenches and can be sold out in market as manure. The empty trenches can again be used for receiving further batches of refuse.

Size of trench $=10 \mathrm{~m} * 1 \mathrm{~m} * 1.5 \mathrm{~m}$

Volume of trench $=15 \mathrm{~m}^{\mathrm{a}}$

Now, we have solid waste generation in 8 days $=27 \mathrm{~m}^{\mathrm{a}}$

According to characterization of waste ( Fig.1), 47\% of total solid waste is decomposable. Hence, generation of decomposable waste is taken as $50 \%$ of total solid waste generation in 8 days.

Generation of decomposable waste $=0.5 * 27=13.5 \mathrm{~m}^{\mathrm{a}}=14 \mathrm{~m}^{\mathrm{a}} \times$ Say

Hence, for decomposing monthly generated decomposable waste four trenches are required. As it takes four months for complete decomposition of waste, used trenches can be reused after period of four months. Hence total sixteen trenches will be required for decomposing annually generated decomposable waste.

Total area required for sixteen trenches $=10 \mathrm{~m} * 1 \mathrm{~m} * 16=160 \mathrm{~m}^{2}$.

By considering space required for operation of vehicles and equipment space of $1.8 \mathrm{~m}$ should be provided around each trench. Hence, total land required is $650 \mathrm{~m}^{2}$.

\section{Training of Workers}

The manual workers are to be trained to understand and adopt the new methods and tools and do not revert to the old system. The typed of brooms now used are inadequate for deposits on roads. These should be replaced by push brooms with handle about $1.5 \mathrm{~m}$ in length to which is attached a wooden block fixed with properly secured fibers. The other important need is to supply hand trolleys of suitable design with light tubular body on wheels with ball bearing with capacity of 200 to 300 liters and arrangements to hold the broom and shovel. Training of all categories employed in this field has to be a periodic process. The most important need is to be a make the technicians attend a course of solid waste management. Project oriented training programs can be arranged as in-house training programs which will help implement the planned proposals in this subject.

The periodical training programs can be worked for following audiences -

1. Managerial

2. Supervisors

3. Design engineers in Public health

4. General public

5. Corporate officers and industrial plant managers

6. School children's

The programs can vary from Seminar or Workshop type programs to T.V., Radio and Public Service announcements. For each category various programs can be designed with the areas of knowledge appropriate to each category.

\section{Conclusion}

This study provides an opportunity to local decision makers to choose the best technologies for the processing of solid waste on the basis of detailed characterization of solid waste. The characterization shows that quantity of rubbish is small as compared to garbage, as large quantities of papers, plastics, cardboards; rags, etc. are picked by the rag pickers. This reduces the calorific value of waste. Also moisture content of waste is high, it cannot be easily burnt or incinerated, and hence the incineration method of waste disposal is not suitable for this type of waste. Hence, Bangalore method of composting suggested for disposal of solid waste. The adoption of suggested solid waste management plan will keep village campus clean and healthy. This will not only contributes to the health of communities but also has positive impact on socio-economic conditions. Further we have planned to conduct social awareness programs in nearby villages for keep their surroundings clean and green. 


\section{References}

\section{Journal Papers:}

[1] Aliakbar Mohammadi, Abdoliman Amouei, Hosseinali Asgharnia, Hourieh Fallah, Zeinab Ghanami "A Survey on the Rural Solid Wastes Characteristics in North Iran (Babol)", Environmental Research And Technology, ISSN 22490256, 2(3): 149-153(2012).

[2] Arunabha Majumdar, "Rural Solid Waste Management: Issues \& Action”, Emeritus Fellow, SWRE, Jadavpur University, Member, Sanitation Task Force, Govt. of West Bengal.

[3] Sapna Sethi , (2013), "Characterization of Municipal Solid Wastein Jalandhar City, Punjab, India", Journal of Hazardous Toxic and Radioactive Waste () ASCE / April 2013/ pp. 97-106.

\section{Books:}

[4] S.K.Garg, Sewage disposal and Air pollution engineering (Khanna publishers, 2012).

[5] Ministry of Urban Development, Manual on Solid Waste Management (Government of India, 2000). 